\title{
Research on Financing Methods of China's Shipbuilding
}

\author{
Xionghui Wen \\ School of Business Administration, South China University of Technology, Guangzhou, China \\ Email:393317379@qq.com
}

How to cite this paper: Wen, X.H. (2018) Research on Financing Methods of China's Shipbuilding. Theoretical Economics Letters, 8, 3116-3140.

https://doi.org/10.4236/tel.2018.814194

Received: August 20, 2018

Accepted: October 22, 2018

Published: October 25, 2018

Copyright (C) 2018 by author and Scientific Research Publishing Inc. This work is licensed under the Creative Commons Attribution International License (CC BY 4.0)

http://creativecommons.org/licenses/by/4.0/

\begin{abstract}
Internationally, shipbuilding industry is in the low stage of development and its financing is in trouble now. According to Petrofin Research, a research firm, since the financial crisis in 2008, the global total ship financing has been reduced, and European banks tend to take a tightening policy towards shipbuilding financing, as the world's top 40 banks reduce investment in shipbuilding industry year after year. In addition, shipping market is also sluggish, of which the global container shipping company in 2011 caused a total loss of up to 5.2 billion US dollars, and the BDI index fell below the lowest point in 26 years. In recent years, although the shipping market has occasionally recovered, but is only a flash in the pan, still difficult to get out of the stagnant situation. With western Banks reducing their support for ship financing, the ship industry began to shift to the east, especially China, and Chinese Banks were gradually favored by the outside world. However, Chinese Banks is less contact with the ship financing, and lack of industry experience, their financing model of the industry is not mature, combined with the high risk characteristics of shipbuilding industry, ordinary financial institutions and shipbuilding enterprises have no systematic understanding of risk influencing factors and preventive measures of shipbuilding enterprises' financing. Under such circumstances, the financing difficulty of Chinese shipbuilding enterprises is even more difficult. This paper expounds the relevant theoretical basis and development status of ship financing, and summarizes the current situation of financing domestic and abroad and the main financing methods, as well as problems faced by shipbuilding enterprises during financing process. At the same time, this paper adopts the method of combination of factor analysis and multiple regression analysis to analyze the sample data of 12 listed shipbuilding enterprises in China during the five-year period of market downturn, to construct a financing mode selection model, and then provide scientific reference for the financing mode selection of shipbuilding enterprises.
\end{abstract}




\section{Keywords}

Ship Financing, Factor Analysis, Logistic Regression

\section{Introduction}

\subsection{Significance}

Ship financing refers to the general term of loan guarantee and other credit businesses that take ship assets as the main pledged object to meet the borrower's demand for building, purchasing, leasing, maintenance and using ship assets. Ship financing itself has the characteristics of large financing demand, long recycling cycle and high investment risk. However, the current global economic slowdown, dominated by European and American areas appear even inverse globalization cold snap, will cause serious impact on global trade as a trade exporter, on the one hand, export trade in our country, especially in shipbuilding export trade will be inevitable contraction, on the other hand, the demand for ships will further reduce in domestic market, what's worse, the shipbuilding industry in our country has just experienced a long boom and has not establish a reliable financing system to deal with the shipbuilding industry turndown caused by financial crisis, which further increases the investment risk and difficulty of the shipbuilding financing.

Shipbuilding enterprises generally take 2 - 3 years or more to complete production after receiving orders, which means that the crisis of shipbuilding enterprises really comes in the post-financial crisis period. According to statistics published by Petrofin, in 2013, the total global ship financing in November was 475 billion US dollars, reducing 5\% year-on-year, which is the lowest point of the world's top 40 banks in terms of investment in shipbuilding industry during the past five years, compared with $9 \%$ in 2008 , with only US $\$ 422.1$ billion. Besides, European Banks have also adopted a tight ship financing policy, the proportion of financing for the ship industry has declined significantly. In recent years, capital has become increasingly a bottleneck for the development of shipbuilding enterprises in China. The main reason is that the shipbuilding financing system in China is not yet sound. Many financial institutions and commercial banks, at the initial stage of exploration of shipbuilding financing, failed to meet the financial needs of shipbuilding enterprises in time, which seriously restricted their development.

Under the background of such depression, the shipbuilding enterprises of our country are walking on thin ice. Whether they can win the order and finance the completion of the order with the minimum risk is directly related to the survival of the small and medium-sized shipbuilding enterprises in our country. This paper makes an in-depth analysis of the financing methods of small and medium-sized shipbuilding enterprises in the current economic environment, and attempts to establish a model system of financing methods selection, so as to 
help Chinese shipbuilding enterprises to choose effective financing methods with low risks in the current sluggish environment.

\subsection{Summary of Research}

Guo Xiaohe and Qu Linchi analyzed and combed China's ship financing pattern and channels, and believed that China's ship financing system has been difficult to cope with the current international shipping development [1]. Deng $\mathrm{Lu}$ pointed out that modern ship financing has the characteristics of large capital demand, long payback period, high financing risk and diversified financing channels [2]. Shao Ruiqing proposed that shipping companies should have the characteristics of diversified sources of funds, and can combine financing in various ways such as import and export credits and financial leasing [3]. Xie Wei researched and pointed out that Chinese boat companies often need to bear relatively high financing risks because of the imperfect management system and small scale. In order to help reduce the risk of bank loans, it is necessary to build a supply chain financing information platform for these Chinese ship building companies and provide guarantee information [4]. Han Lixin, Li Tiansheng pointed out that the ship under construction is a dynamic aggregate, and it is difficult to evaluate the assets used for mortgage [5]. Zheng Lei proposed that with the continuous improvement and strictness of the banking supervision system, shipowners had to mix more of their own capital to reduce the risk level of banks [6]. Wu Yijun pointed out in the article that the shipbuilding enterprise combines production and operation with capital management by establishing a good relationship with the shipowner, and at the same time uses various financing methods to solve the problem of lack of funds [7]. Wang Lixiu pointed out that solving the problem of financial difficulties in the shipbuilding industry can start from promoting the innovation of ship financing business, such as issuing repayment guarantee letters for ships under construction, actively utilizing and expanding non-credit financing, introducing large-scale enterprises to participate in leasing companies, and encouraging Large enterprises establish financial companies to enhance the ship industry's ability to withstand risks by centrally allocating funds [8]. Ge Anxia proposed to learn the ways in which large enterprises commonly used in Japan and Taiwan can drive small enterprises. On the one hand, they can achieve a win-win situation among enterprises, on the other hand, they can realize the improvement of the management system of shipbuilding enterprises [9].

In the field of foreign ship financing research, Goulielmos analyzed the business processes of various types of ship finance leasing in the "new model of ship financing", and discussed the potential risks of the relevant aspects of ship financing leasing [10]. Andy Yeo and $\mathrm{Ng}$ Ee Shen illustrate the importance of using equity financing in Asian shipping companies, and creatively propose two financing methods: after-sale leaseback and convertible corporate bonds [11]. Alfred C. and Stefan Albertijn believe that ship companies face a variety of risks. When corporate bank loans are transferred to other financing methods, compa- 
nies need to assess the specific impact of each risk on the company, and choose which risks to take and reduce themselves risk of loss [12]. In foreign research on risk identification, Wolfgang Bessler, Stefan Albertijn and Wolfgang Drobetz pointed out that in the financial crisis, the income of shipbuilding enterprises may be extremely changed, and the financing risk will have a relatively large impact on the financing methods of shipbuilding enterprises [13]. Chien-Chang Chou, Tzeu-Chen Han and Chih-Ming Wang constructed a method for comprehensive measurement of shipbuilding financing risks. Based on the regression model, Monte Carlo simulation experiments were carried out. Applying this model can effectively identify and control most of the financing risks of shipbuilding enterprises [14]. Haim Levya and Marshall Sarnat deeply analyzed the various risks that may occur in the financing method of ship finance leasing, and put forward corresponding preventive measures for various risks [15]. Qualitative research on financing risk assessment methods Foreign scholars have more academic achievements. Billio Monica applied principal component analysis to identify the systemic risks of the financing process and further studied the relationship between market returns and systemic risks [16]. Dragana Makajic Nikolica and Sandra Jednaka used an analytic hierarchy process and failure model to conduct a more comprehensive analysis of the financing risks of the Serbian power industry, helping partners in the power industry to understand the financing risks [17]. Jyoti P Gupta and Anil K Sravat applied the Monte Carlo method to risk assessment of a power project in India and proposed a risk prevention strategy for applicability [18]. Sadoullah Ebrahimnejada and Seyed Meysam Mousavib proposed that the factors affecting project financing risk are complex, which further increases the possibility of financing risks. The fuzzy multi-attribute decision-making method is used to evaluate the financing risk of a project and guide the financing decision-making process [19].

Generally speaking, there are few in-depth analyses and studies on the financing of ship enterprises in the current research, and a large part of the research is to put forward countermeasures on the problem, which is not very logical, without a solid research system to support its conclusion. In view of the shortcomings of the above research, this paper analyzes the risks of financing in China according to the specific situation of China's shipbuilding enterprises in the post-financial crisis period. Combined with the sample data of several listed shipbuilding companies in China in recent years, it evaluates the ship financing risks of shipbuilding enterprises and proposes influence. The main factors of financing risks of shipbuilding enterprises and the suggestions for preventing ship financing risks help Chinese shipbuilding enterprises to effectively identify and avoid financing risks, and solve financing difficulties to a certain extent.

\subsection{Contributions and Structure}

This paper is mainly aimed at China's shipbuilding enterprises to choose financing methods, this paper has the following contributions: 
In terms of research methods, this paper adopts the combination of factor analysis and logistic regression. Based on qualitative research, real enterprise data is used for quantitative analysis of financing risks, and uncertain financing risks are quantified to guide shipbuilding enterprises to determine financing methods.

From the perspective of research, this paper constructs the financing mode of shipbuilding enterprises from financial dimension and selects model financial indexes, including corporate profitability and debt processing ability, etc., which can directly and quantitatively reflect the business growth of enterprises.

In terms of the data application, this paper comprehensively considers real data of domestic listed shipbuilding enterprises in the past five years, not only from index dimension, but also from the time dimension to analyze each financing methods, so as to ensure the objectivity and representativeness of the analysis results.

The structure of this paper is as follows (Figure 1).

\section{Overview of the Status of Shipbuilding Financing}

\subsection{Supply and Demand Status}

At present, the fund demand of Chinese small shipbuilding enterprises is mainly shown in the following three aspects.

1) Peak demand for funds moved forward.

In the period of market stability, the general shipowner will adopt six node installment payment, and generally pay $80 \%$ of the total price of shipbuilding before delivery, that is, $10 \%$ when signing the contract, $10 \%$ when building the ship starts, $20 \%$ when loading on the ship's berth, $20 \%$ when launching the ship, and $20 \%$ when testing. The remaining $20 \%$ will be paid after delivery. In recent years, the shipbuilding market has been depressed, with $80 \%$ to $90 \%$ of the shipbuilding price being financed by the shipyard. Only $10 \%$ to $20 \%$ of the shipbuilding price is paid before the ship is delivered, and the rest is paid in installments several years after the ship is delivered. In particular, the current market has become a buyer's market. In order to receive orders, shipbuilding enterprises have to agree with the ship owners to reduce the previous pre-payment requirements, further increasing the financial risks facing the ship enterprises.

2) Insufficient orders have caused insufficient supply of funds.

The economic recession caused by the global financial crisis has not yet fully recovered. Due to the lagging nature of the shipping industry, the shipping industry is still in a severe winter, and there is no sign of widespread recovery. At present, only some large shipping enterprises can get enough orders, and it is still difficult for small and medium-sized ships to receive orders. The insufficient orders lead to insufficient cash flow of these small and medium-sized shipping enterprises, which, on the one hand, affects the production schedule of vessels under construction, and on the other hand, has a negative impact on the signing of new orders. 


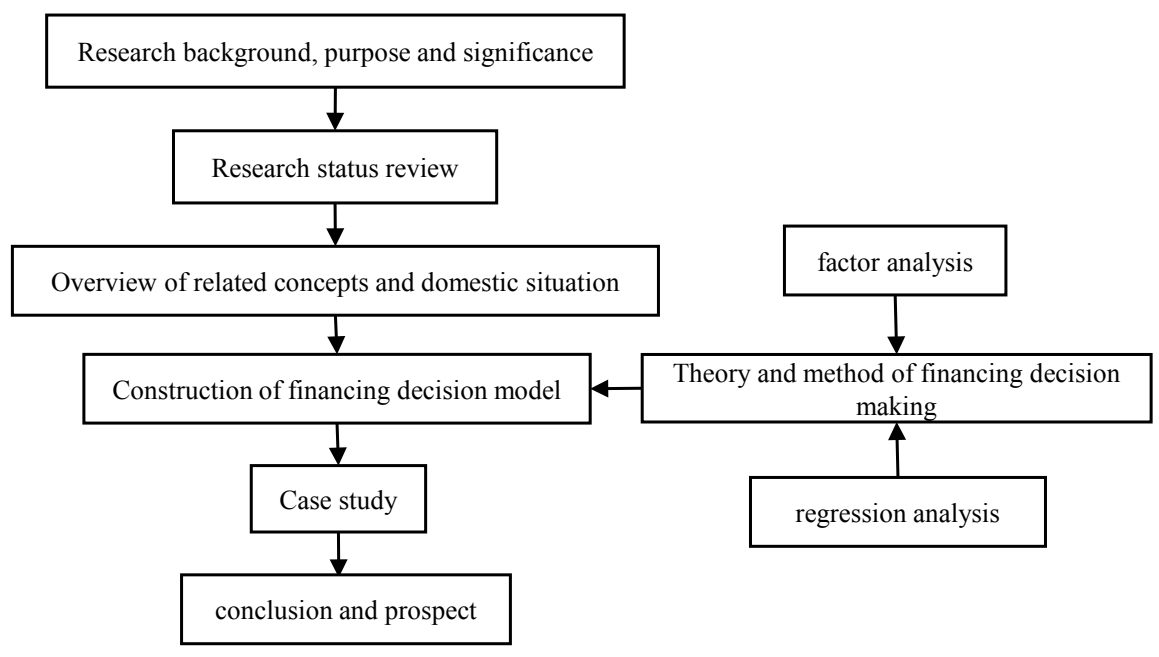

Figure 1. Layout of the whole thesis.

3) Rising production costs add to the capital burden.

With the development of the economy, the raw material costs and labor costs of the shipbuilding industry have increased year by year. In recent years, the central bank has announced the further reform of the exchange rate and the marketization of the exchange rate. Fluctuations in the exchange rate will offset the profits of well-ordered companies and negatively affect the price of new orders. In addition, as the current market is in the buyer's market, shipbuilding enterprises have low bargaining power and strong bargaining power of ship owners. In order to obtain orders, all shipbuilding enterprises are forced into price wars and form vicious competition. In addition, the promulgation of new specifications such as the new standard of target ship type and the new standard of coating protection forced shipbuilding enterprises to carry out technological upgrading, which will undoubtedly further increase the cost of enterprises.

\subsection{Main Way of Financing for Shipbuilding Enterprises in China}

Financing and advance payment by ship owners are the main sources of funds in the process of ship construction, and the progress payment by ship owners is stipulated in the contract as five stages: contract signing, start-up, boarding, launching, and delivery. If there is a funding gap at any of these stages, shipbuilders will need to secure financing to make the ship building project go smoothly. At present, China's shipbuilding financing methods mainly include loan financing, securities market financing, ship leasing financing, internal financing and some other new financing methods.

\subsubsection{Loan Financing}

Loan financing is a traditional financing mode of shipbuilding enterprises, which mainly includes government financing and bank financing, among which bank financing is still the main method of shipbuilding financing in China up to now. Generally, the approval process for government loans is strict and complex, and only large state-owned shipping enterprises can pass the approval. For 
example, China applies preferential tax policies such as levying the value-added tax of the shipping industry first and then returning to import Marine components. Bank loans are a traditional and common financing method, mainly including mortgage credit loans and policy Banks, which are very strict in the examination and approval of credit loans. Therefore, it is necessary to comprehensively evaluate the financial health and development prospects of shipbuilding enterprises, and take into account the debt ratio and cash flow of enterprises. In recent years, the shipping market has been in a downturn, and Banks have drawn up a list of major state-owned enterprises that are relatively easy to obtain credit from Banks. However, most Banks are very cautious about the credit of medium and small sized shipyards, which is difficult and small. When applying for a mortgage loan, it takes the ship under construction as the collateral. As the collateral is under construction, there is a relatively large risk and it is in the consideration of risk avoidance, the general bank will only approve the project loan financing policy that has been insured by China credit insurance. The policy bank loan of shipbuilding enterprises refers to the subsidized loan provided by China for shipping enterprises to promote the export of ships.

\subsubsection{Securities Market Financing}

The securities market mainly refers to the bond, stock and fund markets. Before issuing bonds, shipping enterprises should first pass the assessment of bond rating agencies and grade them. Only enterprises whose grades meet the national standards are qualified to issue bonds. The stock financing threshold is higher, only the powerful large shipping enterprises are generally qualified to use stock financing, most small and medium-sized shipping enterprises are difficult to enter the stock market. In equity financing, investors can not withdraw in the middle of the process, and to a certain extent can guarantee the stability of business and capital integrity. In addition, stock financing is also beneficial to decentralize business risk and increase the credit value of the company, which is a financing method widely adopted by large domestic shipbuilding and shipping enterprises.

\subsubsection{Shipping Financing Lease}

Ship finance lease is the combination of financial industry and shipping industry, it is a kind of finance lease model with ship as the subject matter. This financing mode separates the right to use and the ownership of the ship. The shipowner enjoys the ownership of the ship through the purchase of the ship, and the charterer enjoys the right to use the ship through the lease contract. On the one hand, the ship financing leasing model has alleviated the capital turnover pressure of shipping companies and the construction fund pressure of shipbuilding enterprises. On the one hand, the ship finance leasing model relieves the capital turnover pressure of shipping enterprises and construction capital pressure of shipbuilding enterprises. On the other hand, it creates good investment opportunities for investors, which is a win-win financing model.

At present, the ship finance lease models widely used include direct finance 
lease, after-sale finance lease and leveraged leasing [20].

\subsubsection{Internal Financing}

Internal financing is a kind of financing carried out by enterprises on the basis of their internal accumulation, which includes three forms: capital, the replacement investment converted into depreciable funds, and the new investment into which retained earnings are converted.

Internal financing is highly autonomous, financing costs are low, and the earnings and control of the original shareholders are not diluted. However, internal financing is affected by the company's profitability and accumulation, and the scale of financing is greatly restricted. It is impossible to carry out large-scale financing. The proportion of dividends distributed will be limited by certain shareholders, who may consider the dividend payout ratio to be maintained at a certain level. Too little dividend payment is not conducive to attracting institutional investors with dividend preference, reducing the attractiveness of corporate investment. Too few dividends may affect future external financing. The payment of dividends is very small, which may indicate that the company's profitability is poor, the company's cash is relatively tight, and it does not meet the conditions of some external financing.

\subsubsection{Other Financing Methods}

Other financing methods include private equity fund market financing, trust financing, mezzanine financing and other new financing methods. Since the global financial crisis in 2008, banking industry began to withdraw from the shipbuilding market, at the same time the private equity fund market grew rapidly, one representative equity fund model in Asia of which is the Singapore Maritime Trust Fund.

\section{Construction of Financing Decision Model for Shipbuilding Enterprises}

The risks that shipbuilding enterprises face are unavoidable or uncontrollable systematic risks, including macroeconomic risk policy risk, market risk, exchange rate risk and so on; There are also non-systematic risks that can be self-controlled and self-adjusted, including corporate governance risks, corporate financial risks and technical risks, etc. Since system risk is a risk factor that cannot be controlled outside the enterprise, this paper does not incorporate system risk into the risk assessment system. At the same time, as the assessment of technical risk has professional requirements for the evaluation of indicators, technical risk is not included in the scope of the risk assessment system. This paper mainly considers the financial risk of the company in the non-systematic risk, and summarizes the influencing factors of financing decision.

\subsection{Composition of Influencing Factors of Financing Decision}

The research in this paper analyzes the financing risks of enterprises from three 
aspects: solvency, operating capacity and profitability (Table 1).

Solvency, that is, the company's ability or guarantee to deal with debts, is the strength of the company to use assets to deal with long-term and short-term debts, which can show the company's financial health and survival strength. Generally speaking, the better a company's debt processing ability is, the stronger its health and survival ability are. This paper selects cash ratio, current ratio, quick ratio, and accounts payable turnover rate to reflect the debt handling capacity of shipbuilding enterprises.

Operational ability is the ability of a company to use its assets to generate revenue. It can represent the flow and operation of the company's assets, as well as the efficiency of the company's assets. In general, the better a company's operational capabilities, the higher its operational management. This paper selects the total asset turnover rate, current asset turnover rate, inventory turnover rate, and total asset turnover rate to measure the operational capacity of shipbuilding enterprises.

Profitability, that is, the ability of the company to obtain profits, is the core index that enterprise managers and investors pay close attention to. It is the concrete manifestation of enterprise operation performance and management results, and also the main guarantee of employee welfare. This paper selects the earnings per share, the asset-liability ratio, the net profit margin of the total assets, and the net profit of the shareholders of the parent company to reflect the profitability of a shipbuilding enterprise.

\subsection{Basic Principle of Factor Analysis}

Factor analysis is a multivariate statistical method, which is widely used in the fields of economic management engineering and risk assessment [21]. Using the idea of dimensionality reduction, several representative factors are extracted from many original variables as a measure of the characteristics of the thing, but

Table 1. Variables affecting financing decisions.

\begin{tabular}{|c|c|c|}
\hline Variable & Name & Description \\
\hline $\mathrm{X} 1$ & Net profit margin $(\%)$ & net margin/operating income $\times 100 \%$ \\
\hline $\mathrm{X} 2$ & $\begin{array}{l}\text { Return on total assets } \\
\quad \text { (annualized) }(\%)\end{array}$ & net margin/Total average assets $\times 100 \%$ \\
\hline $\mathrm{X} 3$ & Earnings per share (yuan) & $\begin{array}{c}\text { basic earnings attributable to ordinary shareholders } \\
\text { /weighted average number of ordinary shares } \\
\text { outstanding during the year }\end{array}$ \\
\hline $\mathrm{X} 4$ & Total assets turnover & operating income/total assets \\
\hline $\mathrm{X} 5$ & Accounts receivable turnover & $\begin{array}{c}\text { Net credit sales/average balance of accounts } \\
\text { receivable }\end{array}$ \\
\hline $\mathrm{X} 6$ & Inventory turnover ratio & operating income/Average stock balance \\
\hline $\mathrm{X} 7$ & Liquid ratio & current assets/current liabilities \\
\hline $\mathrm{X} 8$ & Quick ratio & quick assets/current liabilities \\
\hline X9 & Cash ratio & $\begin{array}{c}\text { (currency capital }+ \text { financial assets held for trading)/ } \\
\text { current liabilities }\end{array}$ \\
\hline
\end{tabular}


there is a premise that there should be a strong correlation between these original variables. In this way, several common factors reflecting the commonality can be extracted. There are many ways to test the correlation of these factors, and the correlation matrix of these variables can be calculated. If many correlation coefficients are greater than 0.3 , these variables have strong correlation; SPSS can also be used to test the correlation of variables, SPSS Inspection methods mainly include Bartlett test, KMO test (i.e. Kaiser-Mayer-Olkin test). Bartlett test, that is, by determining the $\mathrm{P}$ value and the level of significance to determine whether the thing is suitable for factor analysis, when the $\mathrm{P}$ value is less than 0.05 , it means that it is applicable. The KMO test is based on the calculation of the correlation coefficient and the partial correlation coefficient to obtain the KMO value. By comparing with the standard, it is judged whether the factor analysis method is applicable. The judgment criteria are as follows:

$\mathrm{KMO}>0.9$, perfectly suitable

$0.8<\mathrm{KMO}<0.9$, relatively suitable

$0.7<\mathrm{KMO}<0.8$, suitable

$0.6<\mathrm{KMO}<0.7$, still suitable

$\mathrm{KMO}<0.5$, not suitable

The main steps of factor analysis include: determining factor variables, naming interpretation of factor variables, and calculating factor values.

\subsection{Basic Principle of Logistic Regression}

When dependent variable is classified and there is no linear relationship between independent variable and dependent variable, the assumption condition of linear regression model is destroyed. At this time, the best choice is logistic regression model, which has no requirements of distribution of dependent variables. From a mathematical point of view, logistic regression model cleverly avoids distribution problem of subtyped variables, which makes up for the shortcomings of linear regression models and generalized linear regression models perfectly. Similar to linear regression analysis, logistic regression analysis can estimate the numerical influence of each independent variable on the probability of taking a certain value of the dependent variable in the case that other independent variables are fixed and unchanged.

When there are several independent variables, the logistic probability function is as below:

$$
p=\frac{\mathrm{e}^{\left(\beta_{1} x_{1}+\beta_{2} x_{2}+\cdots+\beta_{m} x_{m}+\beta_{0}\right)}}{1+\mathrm{e}^{\left(\beta_{1} x_{1}+\beta_{2} x_{2}+\cdots+\beta_{m} x_{m}+\beta_{0}\right)}}
$$

$P$ represents the probability of an event occurring. $x_{1}, x_{2}, \cdots x_{m}$ are arguments. $\beta_{0}, \beta_{1}, \cdots \beta_{m}$ are regression coefficients.

The above equation is further deformed to obtain the following formula:

$$
\ln \frac{p}{1-p}=\sum \beta_{i} x_{i}
$$




\subsection{Construction Logic of the Decision Model}

The financing decision of shipbuilding enterprises needs to take different risk factors into consideration, including the specific indexes of the industry, such as asset-liability ratio, current ratio, quick ratio, as well as the indexes that will be assessed by each industry, such as operating income growth rate and net profit growth. In order to effectively identify the financing risks of shipbuilding enterprises and make financing decisions, it is necessary to construct a financing decision model that is effective in the industry, the construction ideas are as follows:

1) Determination of indicators

This paper studies the financing decisions of shipbuilding enterprises from the perspective of financial risks, and selected original variables are shown in Table 1.

\section{2) Determination of impact factors}

After determining these original variables of financing risk, factor analysis is used to add financial data of 12 listed companies of shipbuilding industry to extract common factors.

\section{3) Determination of the regression equation}

On the basis of factor analysis, polynomial regression and logistic regression are adopted to obtain the relationship between extracted common factors and internal financing rate, short-term financing rate, long-term financing rate and equity financing rate respectively.

\section{4) Empirical test}

An empirical analysis will be conducted to test the accuracy of the regression model by comparing predicted and actual values of the regression equation.

\section{Empirical Analysis of Financing Decision}

\subsection{Sample Company Selection}

In order to better study the financing mode decision of shipbuilding enterprises, this paper needs to introduce some shipbuilding enterprises as samples. In view of the availability of data and the representativeness of sample enterprises, this paper will select companies listed on Shenzhen and Shanghai stock exchange, and make the following screening of samples: 1) Eliminate abnormal company data to ensure that the data can reflect the normal development of listed companies; 2) Only choose domestic A-share listed companies, due to the difference in share price in different secondary markets, $\mathrm{B}$ shares and overseas listed companies are not considered; 3) Eliminate companies with incomplete or missing data.

This paper finally adopted 12 listed companies as research samples. Among them, ${ }^{\star}$ ST Barge, Tianhai Defence, Sunbird, Steel Structure Engineering, China Shipbuilding, China Shipbuilding Defense, Yaxing Anchor Chain, China Heavy Industry are main listed companies in shipbuilding industry, and Baoding Technology, Chaiwei Heavy Machinery, Zhenhua Heavy Industry and Dalian 
Heavy Industry provide parts for ships. Therefore, these four companies were also selected as research samples. Data of the 12 companies between 2013 and 2017 are collected for processing and analysis, which is processed by the method of averaging five years' financial data. Sample companies selected are shown in Table 2.

\subsection{Factor Analysis}

\subsubsection{Independent Variable Correlation Test}

Before doing factor analysis, the correlation test should be carried out on the nine variables selected in Table 2. Only when calculated correlation is high, the principal factor analysis can be done. Here we use KMO and Bartlett sphere test.

As shown in the above Table 3, the KMO value is 0.661 . According to the judgment rule mentioned above, when $0.6<\mathrm{KMO}<0.7$, the data is suitable for factor analysis. In addition, the significance value in the table is 0.000 , which lower than 0.05 , indicating that the selected nine variables are related and suitable for factor analysis.

\subsubsection{Common Factor Extraction}

Using SPSS statistical software for factor analysis, extraction method selects principal component analysis, and the results are as follows (Table 4).

According to Table 4, the cumulative contribution rate of the first three common factors is as high as $96.713 \%$, which means that the ability of the former three common factors to explain the information contained in the original data variance is satisfying. Therefore, only the former three common factors are selected to replace the original nine independent variables.

Table 2. Selected sample companies.

\begin{tabular}{ccc}
\hline Company Number & Name & Stock code \\
\hline 1 & ${ }^{*}$ ST Barge & $002608 . \mathrm{SZ}$ \\
3 & Tianhai Defence & $300008 . \mathrm{SZ}$ \\
4 & Sunbird & $300123 . \mathrm{SZ}$ \\
5 & Steel Structure Engineering & $600072 . \mathrm{SH}$ \\
6 & China Shipbuilding & $600150 . \mathrm{SH}$ \\
7 & China Shipbuilding Defense & $600685 . \mathrm{SH}$ \\
8 & Yaxing Anchor Chain & $601890 . \mathrm{SH}$ \\
9 & China Heavy Industry & $601989 . \mathrm{SH}$ \\
10 & Baoding Technology & $002552 . \mathrm{SH}$ \\
11 & Chaiwei Heavy Machinery & $000880 . \mathrm{SZ}$ \\
12 & Zhenhua Heavy Industry & $600320 . \mathrm{SH}$ \\
\hline
\end{tabular}

Source: Shenzhen Stock Exchange; Shanghai Stock Exchange. 
Table 3. KMO and Bartlett's test.

\begin{tabular}{lcc}
\hline \multicolumn{2}{c}{ KMO value } & 0.661 \\
\hline & Approximated chi square & 144.957 \\
Bartlett's sphericity test & Degree of freedom & 36 \\
& Significance & 0.000 \\
\hline
\end{tabular}

Source: SPSS.

Table 4. Total variance of interpretation.

\begin{tabular}{|c|c|c|c|c|c|c|c|c|c|}
\hline \multirow{2}{*}{ Variables } & \multicolumn{3}{|c|}{ Initial eigenvalue } & \multicolumn{3}{|c|}{ Extraction square sum loading } & \multicolumn{3}{|c|}{ Rotation square sum loading } \\
\hline & Total & Variance $\%$ & Accumulation \% & Total & Variance $\%$ & Accumulation \% & Total & Variance $\%$ & Accumulation \% \\
\hline 1 & 3.902 & 43.352 & 43.352 & 3.902 & 43.352 & 43.352 & 3.041 & 33.784 & 33.784 \\
\hline 2 & 3.412 & 37.906 & 81.259 & 3.412 & 37.906 & 81.259 & 2.940 & 32.664 & 66.448 \\
\hline 3 & 1.391 & 15.455 & 96.713 & 1.391 & 15.455 & 96.713 & 2.724 & 30.265 & 96.713 \\
\hline 4 & 0.163 & 1.809 & 98.522 & & & & & & \\
\hline 5 & 0.062 & 0.685 & 99.207 & & & & & & \\
\hline 6 & 0.050 & 0.553 & 99.759 & & & & & & \\
\hline 7 & 0.014 & 0.154 & 99.914 & & & & & & \\
\hline 8 & 0.005 & 0.060 & 99.974 & & & & & & \\
\hline 9 & 0.002 & 0.026 & 100.000 & & & & & & \\
\hline
\end{tabular}

Source: SPSS.

It can be seen from Table 5 that the net profit margin (\%), earnings per share (yuan), return on total assets (annualized) (\%) has a larger load on the first common factor. They are indicators that reflect the profitability of a company, so the first common factor is named "profitability". The total asset turnover, accounts receivable turnover, and the inventory turnover rate have a larger load in the second common factor, which are indicators that reflect the operational capacity of an enterprise, then naming the second common factor as "Operating Capability". The rest cash ratio, quick ratio, and cash ratio have large loads in the third common factor, which are indicators that reflect the solvency of an enterprise, thus the third common factor is named "Solvency".

\subsubsection{Common Factor Score}

According to the factor score matrix (Table 6), the formulas for calculating three common factors can be obtained as follows:

$$
\begin{aligned}
f_{1}= & 0.357 \times x_{1}+0.328 \times x_{2}+0.366 \times x_{3}-0.047 \times x_{4}-0.129 \times x_{5} \\
& +0.019 \times x_{6}-0.073 \times x_{7}-0.062 \times x_{8}+0.071 \times x_{9} \\
f_{2}= & -0.071 \times x_{1}-0.026 \times x_{2}-0.099 \times x_{3}+0.071 \times x_{4}+0.076 \times x_{5} \\
& +0.044 \times x_{6}+0.358 \times x_{7}+0.359 \times x_{8}+0.376 \times x_{9} \\
f_{3}= & -0.070 \times x_{1}-0.032 \times x_{2}-0.065 \times x_{3}+0.377 \times x_{4}+0.391 \times x_{5} \\
& +0.346 \times x_{6}+0.035 \times x_{7}+0.046 \times x_{8}+0.104 \times x_{9}
\end{aligned}
$$


Table 5. Rotation factor load matrix.

\begin{tabular}{ccccc}
\hline \multirow{2}{*}{ Variable name } & \multicolumn{3}{c}{ Ingredient } & \\
\cline { 2 - 5 } & 1 & 2 & 3 & \\
Net profit margin (\%) & 0.980 & 0.167 & 0.080 & \\
Return on total assets (annualized) (\%) & 0.954 & 0.245 & 0.132 & Profitability $f_{1}$ \\
Earnings per share (yuan) & 0.984 & 0.087 & 0.122 & \\
Total assets turnover & 0.153 & -0.115 & 0.946 & \\
Accounts receivable turnover & -0.084 & -0.183 & 0.928 & Operating capacity $f_{3}$ \\
Inventory turnover ratio & 0.310 & -0.111 & 0.921 & \\
Liquid ratio & 0.123 & 0.960 & -0.216 & \\
Quick ratio & 0.165 & 0.966 & -0.180 & Solvency $f_{2}$ \\
Cash ratio & 0.188 & 0.965 & -0.040 & \\
\hline
\end{tabular}

Source: SPSS.

Table 6. Factor score matrix.

\begin{tabular}{ccccc}
\hline Variable name & \multirow{3}{*}{ Symbol } & \multicolumn{3}{c}{ Common factor } \\
\cline { 4 - 5 } & & Profitability $f_{1}$ & Solvency $f_{2}$ & Operating capacity $f_{3}$ \\
\hline $\begin{array}{c}\text { Net profit margin (\%) } \\
\text { Return on total assets }\end{array}$ & $x_{1}$ & 0.357 & -0.071 & -0.070 \\
$\quad \begin{array}{c}\text { (annualized) (\%) } \\
\text { Earnings per share (yuan) }\end{array}$ & $x_{2}$ & 0.328 & -0.026 & -0.032 \\
Total assets turnover & $x_{3}$ & 0.366 & -0.099 & -0.065 \\
Accounts receivable turnover & $x_{4}$ & -0.047 & 0.071 & 0.377 \\
Inventory turnover ratio & $x_{5}$ & -0.129 & 0.076 & 0.391 \\
Liquid ratio & $x_{6}$ & 0.019 & 0.044 & 0.346 \\
Quick ratio & $x_{7}$ & -0.073 & 0.358 & 0.035 \\
Cash ratio & $x_{8}$ & -0.062 & 0.359 & 0.046 \\
\hline
\end{tabular}

Source: SPSS.

By replacing data $x_{i}$ in the calculation formula of the above three common factors with average value $\bar{x}_{i}$, calculation results of Profitability $f_{1}$, Solvency $f_{2}$ and Operating capacity $f_{3}$ of 12 sample companies can be obtained respectively.

\subsubsection{Overall Score}

According to Table 4, eigenvalue $\lambda_{1}=3.902$ corresponding to the common factor $f_{1}$, eigenvalue $\lambda_{2}=3.412$ corresponding to the common factor $f_{2}$, and the eigenvalue $\lambda_{3}=1.391$ corresponding to the common factor $f_{3}$.

overall score

$$
F=\frac{\lambda_{1}}{\sum_{i=1}^{3} \lambda_{i}} \times f_{1}+\frac{\lambda_{2}}{\sum_{i=1}^{3} \lambda_{i}} \times f_{2}+\frac{\lambda_{3}}{\sum_{i=1}^{3} \lambda_{i}} \times f_{3}
$$


Substituting the corresponding feature root value into the above formula:

$$
\text { overall score } \quad F=44.83 \% \times f_{1}+39.19 \% \times f_{2}+15.98 \% \times f_{3}
$$

\subsection{Regression Model Construction}

\subsubsection{Judgment Rules on Financing Methods}

Here we mainly analyze the four financing methods most commonly used by shipbuilding enterprises, namely internal financing, short-term financing, long-term financing and equity financing. The utilization ratio of each financing methods within an enterprise is called financing rate, and corresponding calculation formula is as below:

Internal financing rate $y_{1}=$ (Surplus reserve + undistributed profit + Depreciation of fixed assets +Amortization of intangible assets)/Total assets

Short-term financing rate $y_{2}=$ short-term loan/Total assets

Long-term financing rate $y_{3}=$ Long term loan/Total assets

Equity financing is special, once an enterprise chooses equity financing, it means to issue new shares of a certain scale and quantity. Therefore, equity financing only exists in two cases: if the company implements equity financing, the value is 1 ; if the company does not implement equity financing, the value is 0 . This situation where the dependent variable is binary is suitable for binary logistic regression.

Through literature review, this paper selects $5 \%$ as the critical value to determine the financing method selection criteria [22]. 1) Internal financing: if the amount of retained earnings exceeds $5 \%$ of total assets, the enterprise is considered to have conducted internal financing; 2) Short-term borrowing financing: if the enterprise's short-term borrowing increment exceeds $5 \%$ of the total assets at the end of the year, the enterprise is considered to have conducted short-term borrowing financing; 3) Long-term borrowing: If the long-term loan increase of the enterprise exceeds $5 \%$ of the total assets at the end of the year, the enterprise is considered to have conducted long-term borrowing financing; 4) Equity financing: If the company has a share placement, additional issuance or issuance of convertible bonds in the secondary market, the company is considered to have conducted equity financing.

According to the original financial data, the internal financing rate, short-term financing rate and long-term financing rate of 12 sample companies from 2013 to 2017 can be obtained separately. Here, the method of averaging the original financial data for 5 years is used to calculate the average internal financing rate $\bar{y}_{1}$, the average short-term financing rate $\bar{y}_{2}$ and the average long-term financing rate $\bar{y}_{3}$ for the 12 sample companies. In addition, the equity financing situation of the sample enterprises can be determined according to their situation of share placement, additional issuance or issuance of convertible bonds in the secondary market. Calculation results are shown in Table 7.

Based on the principles of polynomial regression and logistic regression introduced above, the regression analysis of internal financing, short-term financing, 
Table 7. Average financing rate calculation of sample company.

\begin{tabular}{ccccc}
\hline $\begin{array}{c}\text { Company } \\
\text { Number }\end{array}$ & $\begin{array}{c}\text { Internal financing } \\
\text { rate } \bar{y}_{1}\end{array}$ & $\begin{array}{c}\text { Short-term } \\
\text { financing rate }\end{array} \bar{y}_{2}$ & $\begin{array}{c}\text { Long-term } \\
\text { financing rate }\end{array}$ & Equity financing \\
\hline 1 & -0.29228 & 0.03893 & 0.02466 & - \\
2 & 0.21609 & 0.03413 & 0.00000 & directional add-issuance \\
3 & 0.11866 & 0.05277 & 0.00788 & - \\
4 & 0.14586 & 0.02743 & 0.03181 & - \\
5 & 0.23635 & 0.02041 & 0.07916 & - \\
6 & 0.16380 & 0.01300 & 0.07756 & directional add-issuance \\
7 & 0.12929 & -0.01233 & 0.01834 & - \\
8 & 0.07983 & 0.01949 & 0.06412 & convertible bond, \\
9 & 0.17426 & 0.02920 & 0.00000 & directional add-issuance \\
10 & 0.10983 & 0.00000 & 0.00000 & - \\
11 & 0.09289 & 0.01742 & 0.02048 & convertible bond \\
12 & 0.10697 & -0.00315 & 0.01060 & $33.3 \%$ \\
\hline 0.05 ratio & $91.7 \%$ & $8.3 \%$ & $25 \%$ & \\
\hline
\end{tabular}

Source of raw data: Wind database.

long-term financing and equity financing will yield the following regression equation :

$$
y_{i}=\alpha_{i}+\beta_{i 1} F+\beta_{i 2} F^{2}+\ldots+\beta_{i m} F^{m}+\varepsilon_{i}, \quad(i=1,2,3)
$$

Equity financing rate $\quad P\left(y_{4}\right)=\frac{\mathrm{e}^{\left(\beta_{1} f_{1}+\beta_{2} f_{2}+\cdots+\beta_{m} f_{m}+\beta_{0}\right)}}{1+\mathrm{e}^{\left(\beta_{1} f_{1}+\beta_{2} f_{2}+\cdots+\beta_{m} f_{m}+\beta_{0}\right)}}$

In the above formulas, $y_{1}$ means internal financing rate, $y_{2}$ means short-term financing rate, $y_{3}$ means long-term financing rate, and $y_{4}$ means equity financing rate, all the four are explanatory variables; $f_{1}$ means the Profitability, $f_{2}$ means the Solvency, and $f_{3}$ means the Operational ability, they are three common factors for calculating the overall score $F ; x_{1}$ represents net profit margin (\%), $x_{2}$ represents earnings per share(yuan), $x_{3}$ represents total net asset interest rate (annualized) (\%), $x_{4}$ represents receivables turnover rate (times), $x_{5}$ represents total asset turnover rate (times), $x_{6}$ represents cash ratio, $x_{7}$ represents liquid ratio, $x_{8}$ represents cash ratio, and $x_{9}$ represents inventory turnover rate (times), they are original independent variables.

\subsubsection{Regression Analysis}

\section{1) Internal financing}

Taking average internal financing rate $y_{1}$ as dependent variable and overall score $F$ as independent variable, SPSS was used to perform various forms of curve regression, and it was found that the binomial regression model fits best (Table 8). 
Table 8. Summary of binomial regression of internal financing rate.

\begin{tabular}{ccccccccc}
\hline \multirow{2}{*}{ Equation } & \multicolumn{4}{c}{ Model summary } & \multicolumn{4}{c}{ Parameter evaluation } \\
\cline { 2 - 9 } & R square & $\mathrm{F}$ & $\mathrm{df1}$ & $\mathrm{df} 2$ & Significance & Constant & $\mathrm{b} 1$ & $\mathrm{~b} 2$ \\
\hline $\begin{array}{c}\text { Quadratic } \\
\text { model }\end{array}$ & 0.913 & 47.008 & 2 & 9 & 0 & 0.144 & 0.111 & -0.106 \\
\hline
\end{tabular}

Source: SPSS.

The formula for calculating internal financing rate is as follows:

Internal financing rate

$$
y_{1}=-0.106 \times F^{2}+0.111 \times F+0.144
$$

\section{2) Short-term financing}

Taking average short-term financing rate $y_{2}$ as dependent variable and overall score $F$ as independent variable, SPSS was used to perform various forms of curve regression, and it was showed that the trinomial regression model fits best (Table 9):

The formula for calculating the short-term financing rate is as follows:

Short-term financing rate $y_{2}=-0.442 \times F^{3}+0.233 \times F^{2}+0.001$

\section{3) Long-term financing}

Taking average long-term financing rate $y_{3}$ as dependent variable and overall score $F$ as independent variable, SPSS was used to perform various forms of curve regression, and the result was that the trinomial regression model fits best (Table 10).

The formula for calculating long-term financing rate is as follows:

$$
\text { Long-term financing rate } y_{3}=-0.047 \times F^{3}-0.109 \times F^{2}-0.024 \times F+0.074
$$

\section{4) Equity financing}

Taking three common factors profitability $f_{1}$, solvency $f_{2}$ and operational capacity $f_{3}$ as independent variables, and whether the sample company has carried out equity financing as dependent variable ( 1 or 0$)$, then Binary logistic regression analysis was conducted with SPSS software (Table 11).

During the statistical analysis, sample data of Sunbird was found to be an abnormal point, so it was deleted. The results of logistic regression analysis on the remaining 11 samples were as follows:

It can be seen from Table 12 that the comprehensive test Sig. values of the model coefficients for the steps, modules and models are all less than 0.05 , which means that these tests are passed.

In Table 13, final model has a log-likelihood value of 3.714. The Cox \& Snell $\mathrm{R}$ square is 0.622 and Nagelkerke $\mathrm{R}$ square is 0.852 , both of which are qualified.

As can be seen from Table 14, the Leme show statistic is significantly greater than 0.1 , indicating that the null hypothesis is accepted and there is no significant difference between the predicted and actual values.

The logistic regression equation for equity financing and three common factors can be obtained from Table 15: 
Table 9. Summary of trinomial regression of short-term financing rate.

\begin{tabular}{ccccccccccc}
\hline \multirow{2}{*}{ Equation } & \multicolumn{4}{c}{ Model summary } & \multicolumn{4}{c}{ Parameter evaluation } \\
\cline { 2 - 11 } & R square & F & df1 & df2 & Significance & Constant & b1 & b2 & b3 \\
\hline Cubic curve model & 0.896 & 14.363 & 3 & 5 & 0.007 & 0.001 & 0.066 & 0.233 & -0.442 \\
\hline
\end{tabular}

Source: SPSS.

Table 10. Summary of trinomial regression of long-term financing rate.

\begin{tabular}{cccccccccc}
\hline \multirow{2}{*}{ equation } & \multicolumn{4}{c}{ Model summary } & \multicolumn{4}{c}{ Parameter evaluation } \\
\cline { 2 - 10 } & R square & F & df1 & df2 & Significance & constant & b1 & b2 & b3 \\
\hline cubic curve model & 0.851 & 7.637 & 3 & 4 & 0.039 & 0.074 & -0.024 & -0.109 & -0.047 \\
\hline
\end{tabular}

Source: SPSS

Table 11. Logistic regression analysis data collation.

\begin{tabular}{|c|c|c|c|c|c|}
\hline $\begin{array}{l}\text { Company } \\
\text { Number }\end{array}$ & Company name & $\begin{array}{c}\text { Equity } \\
\text { financing }\left(\mathrm{Y}_{4}\right)\end{array}$ & Profitability $f_{1}$ & Solvency $f_{2}$ & $\begin{array}{l}\text { Operating } \\
\text { capacity } f_{3}\end{array}$ \\
\hline 1 & ${ }^{*}$ ST Barge & 0 & -3.1150 & -0.3448 & -0.2601 \\
\hline 2 & Tianhai Defence & 1 & 0.2964 & 1.0752 & 0.4178 \\
\hline 3 & Sunbird & 0 & 0.1015 & -0.5752 & -0.5557 \\
\hline 4 & $\begin{array}{l}\text { Steel Structure } \\
\text { Engineering }\end{array}$ & 0 & 0.5718 & -0.6514 & -1.0081 \\
\hline 5 & China Shipbuilding & 0 & 0.2901 & -0.1642 & 0.4870 \\
\hline 6 & $\begin{array}{c}\text { China Shipbuilding } \\
\text { Defense }\end{array}$ & 1 & 0.2851 & -0.2318 & 0.3991 \\
\hline 7 & Yaxing Anchor Chain & 0 & -0.0278 & 1.8425 & -0.2060 \\
\hline 8 & China Heavy Industry & 1 & 0.4327 & -0.5600 & -0.9236 \\
\hline 9 & Baoding Technology & 0 & 0.1490 & 1.8457 & -0.4049 \\
\hline 10 & $\begin{array}{c}\text { Chaiwei Heavy } \\
\text { Machinery }\end{array}$ & 0 & 0.0788 & -0.4938 & 2.7767 \\
\hline 11 & $\begin{array}{c}\text { Zhenhua Heavy } \\
\text { Industry }\end{array}$ & 0 & 0.3098 & -0.9521 & -0.4166 \\
\hline 12 & $\begin{array}{l}\text { Dalian Heavy } \\
\text { Industry }\end{array}$ & 1 & 0.6275 & -0.7900 & -0.3056 \\
\hline
\end{tabular}

Source of raw data: Wind database.

Table 12. Comprehensive test of model coefficients.

\begin{tabular}{ccccc}
\hline & & chi-square & df & Sig. \\
\hline Step 1 & Step & 10.706 & 3 & 0.013 \\
& Piece & 10.706 & 3 & 0.013 \\
& Model & 10.706 & 3 & 0.013 \\
\hline
\end{tabular}

Source: SPSS.

Table 13. Goodness-of-fit test of the model.

\begin{tabular}{cccc}
\hline Step & -2 Log likelihood value & Cox \& Snell R square & Nagelkerke R square \\
\hline 1 & 3.714 & 0.622 & 0.852 \\
\hline
\end{tabular}

Source: SPSS. 
Table 14. Hosmer and Leme show test.

\begin{tabular}{cccc}
\hline Step & Square & Df & Sig. \\
\hline 1 & 2.899 & 8 & 0.941 \\
\hline
\end{tabular}

Source: SPSS.

Table 15. Logistic model variable coefficient table.

\begin{tabular}{cc}
\hline Variable & B \\
\hline Profitability $f_{1}$ & 56.708 \\
Solvency $f_{2}$ & 2.73 \\
Operating capacity $f_{3}$ & 2.045 \\
Constant & -16.775
\end{tabular}

Source: SPSS

$$
\log \left(\frac{p}{1-p}\right)=56.708 \times f_{1}+2.73 \times f_{2}+2.045 \times f_{3}-16.775
$$

Therefore, the probability of equity financing:

$$
p\left(y_{4}\right)=\frac{\mathrm{e}^{\left(56.708 \times f_{1}+2.73 \times f_{2}+2.045 \times f_{3}-16.775\right)}}{1+\mathrm{e}^{\left(56.708 \times f_{1}+2.73 \times f_{2}+2.045 \times f_{3}-16.775\right)}}
$$

When the probability of the predicted value $\mathrm{p}$ is greater than 0.5 , the sample enterprise has an equity financing tendency, and could be considered to have equity financing; on the contrary, when the probability of $\mathrm{p}$ is less than 0.5 , the sample enterprise has no equity financing tendency, so there is no equity financing.

As can be seen from Table 16, the first type error rate (taking false as true) is $1-83.3 \%=12.7 \%$, and the second type error rate (taking true as false) is $1-75 \%$ $=25 \%$, So the comprehensive accuracy rate is $80 \%$. Overall, the fitting effect of the model is satisfactory.

\subsection{Empirical Analysis and Evaluation}

The following four regression equations are used to calculate the internal financing rate $y_{1}$, short-term financing rate $y_{2}$, long-term financing rate $y_{3}$ and equity financing rate $y_{4}$ of these sample companies, then calculated values are compared with actual values to further evaluate the validity of these regression models.

For $y_{1}, y_{2}, y_{3}$, when both the predicted value and actual value are greater than 0.05 , the forecast situation is consistent with actual situation, indicating that selected enterprise has adopted this financing method; when both the predicted value and the actual value are less than 0.05 , it also indicates that the forecast situation is consistent with actual situation, indicating that the sample company has not adopt the financing method in discussion; However, if the predicted value or the actual value is greater than 0.05 and the other is less than 
Table 16. Logistic model prediction results.

\begin{tabular}{|c|c|c|c|c|c|}
\hline & \multirow{3}{*}{ Observed } & & \multicolumn{3}{|c|}{ Observed } \\
\hline & & & \multicolumn{2}{|c|}{ Equity financing } & \multirow{2}{*}{ Percentage correction } \\
\hline & & & 0 & 1 & \\
\hline \multirow{3}{*}{ Step 1} & & 0 & 6 & 1 & 85.7 \\
\hline & Equity financing & 1 & 1 & 3 & 75 \\
\hline & Total percentage & & & & 81.8 \\
\hline \multicolumn{6}{|c|}{ Cutting value 0.500} \\
\hline
\end{tabular}

Source: SPSS

0.05 , it means that the forecast situation is inconsistent with actual situation, at this point, it can be considered as prediction failure.

\subsubsection{Internal Financing}

In Table 17, it is clearly showed that 8 samples have been successfully predicted, which means predicted values is consistent with actual values. And the prediction accuracy is $66.7 \%$.

\subsubsection{Short-Term Financing}

It can be seen from Table 18 below that 10 samples are successfully predicted, which means that predicted values is consistent with actual values. So the prediction accuracy rate is $83.3 \%$.

\subsubsection{Long-Term Financing}

As can be seen from Table 19, 9 samples are successfully predicted, so the prediction accuracy of this regression equation is $75 \%$.

\subsubsection{Equity Financing}

As can be seen from Table 20 and Table 21, the logistic regression model has correctly predicted 8 companies and failed 4 samples, with a comprehensive accuracy rate of $72.7 \%$.

\section{Conclusion and Suggestion}

\subsection{Conclusion}

According to the empirical analysis, there are several conclusions can be drawn:

1) Main financial factors affecting the choice of financing methods for shipbuilding enterprises involve profitability, solvency and operational capacity. Among them, profitability has the greatest impact on determination of financing methods, followed by solvency and finally operational capacity. Different companies have different strengths and weaknesses, which apply to different financing methods. For example, the most profitable shipbuilding companies are suitable for internal financing; the most prominent solvency companies are suitable for debt financing, including long-term financing and short-term financing. 
Table 17. 2017 sample company internal financing rate $y_{1}$.

\begin{tabular}{|c|c|c|c|c|}
\hline \multicolumn{5}{|c|}{ Prediction $y_{1}=-0.195 \times F^{2}+0.109 \times F+0.166$} \\
\hline Company Number & 2017 overall score $F$ & Actual value & Predictive value & Consistence \\
\hline 1 & -78.6082 & -0.2923 & -1213.3557 & $\sqrt{ }$ \\
\hline 2 & 1.7107 & 0.2161 & -0.2182 & $x$ \\
\hline 3 & 1.0300 & 0.1187 & 0.0714 & $\sqrt{ }$ \\
\hline 4 & 1.0482 & 0.1459 & 0.0660 & $\sqrt{ }$ \\
\hline 5 & 0.8801 & 0.2363 & 0.1109 & $\sqrt{ }$ \\
\hline 6 & 1.5085 & 0.1638 & -0.1133 & $x$ \\
\hline 7 & 3.3888 & 0.1293 & -1.7040 & $x$ \\
\hline 8 & -0.2890 & 0.0798 & 0.1182 & $\sqrt{ }$ \\
\hline 9 & 0.6660 & 0.1743 & 0.1521 & $\sqrt{ }$ \\
\hline 10 & 1.2623 & 0.1098 & -0.0071 & $x$ \\
\hline 11 & 0.8675 & 0.0929 & 0.1138 & $\sqrt{ }$ \\
\hline 12 & 0.5201 & 0.1070 & 0.1699 & $\sqrt{ }$ \\
\hline
\end{tabular}

Source of actual value: Wind database.

Table 18. 2017 sample company short-term financing rate $y_{1}$.

\begin{tabular}{|c|c|c|c|c|}
\hline \multicolumn{5}{|c|}{ Prediction $y_{2}=-0.442 \times F^{3}+0.233 \times F^{2}+0.066 \times F+0.001$} \\
\hline Company Number & 2017overall score $F$ & Actual value & Predictive value & Consistence \\
\hline 1 & -78.6082 & 0.0389 & 216131.4666 & $x$ \\
\hline 2 & 1.7107 & 0.0341 & -1.4171 & $\sqrt{ }$ \\
\hline 3 & 1.0300 & 0.0528 & -0.1668 & $x$ \\
\hline 4 & 1.0482 & 0.0274 & -0.1829 & $\sqrt{ }$ \\
\hline 5 & 0.8801 & 0.0204 & -0.0617 & $\sqrt{ }$ \\
\hline 6 & 1.5085 & 0.0130 & -0.8865 & $\sqrt{ }$ \\
\hline 7 & 3.3888 & -0.0123 & -14.3008 & $\sqrt{ }$ \\
\hline 8 & -0.2890 & 0.0195 & 0.0120 & $\sqrt{ }$ \\
\hline 9 & 0.6660 & 0.0292 & 0.0177 & $\sqrt{ }$ \\
\hline 10 & 1.2623 & 0.0000 & -0.4334 & $\sqrt{ }$ \\
\hline 11 & 0.8675 & 0.0174 & -0.0549 & $\sqrt{ }$ \\
\hline 12 & 0.5201 & -0.0032 & 0.0362 & $\sqrt{ }$ \\
\hline
\end{tabular}

Source of actual value: Wind database.

(2) Based on the analysis of the financing methods of the sample enterprises in the past five years, it is concluded that the financing order of current shipbuilding enterprises is internal financing, equity financing, long-term financing and short-term financing. During the market downturn, most of the shipbuilding enterprises' orders fell, and the payback period became longer, which has 
Table 19. 2017 sample company long-term financing rate $y_{3}$.

\begin{tabular}{|c|c|c|c|c|}
\hline \multicolumn{5}{|c|}{ Prediction $y_{3}=-0.047 \times F^{3}-0.109 \times F^{2}-0.024 \times F+0.074$} \\
\hline Company Number & 2017 overall score $F$ & Actual value & Predictive value & Consistence \\
\hline 1 & -78.6082 & 0.0247 & 22158.1822 & $x$ \\
\hline 2 & 1.7107 & 0.0000 & -0.5214 & $\sqrt{ }$ \\
\hline 3 & 1.0300 & 0.0079 & -0.1177 & $\sqrt{ }$ \\
\hline 4 & 1.0482 & 0.0318 & -0.1251 & $\sqrt{ }$ \\
\hline 5 & 0.8801 & 0.0792 & -0.0636 & $x$ \\
\hline 6 & 1.5085 & 0.0776 & -0.3716 & $x$ \\
\hline 7 & 3.3888 & 0.0183 & -3.0882 & $\sqrt{ }$ \\
\hline 8 & -0.2890 & 0.0641 & 0.0730 & $\sqrt{ }$ \\
\hline 9 & 0.6660 & 0.0000 & -0.0042 & $\sqrt{ }$ \\
\hline 10 & 1.2623 & 0.0000 & -0.2245 & $\sqrt{ }$ \\
\hline 11 & 0.8675 & 0.0205 & -0.0595 & $\sqrt{ }$ \\
\hline 12 & 0.5201 & 0.0106 & 0.0254 & $\sqrt{ }$ \\
\hline
\end{tabular}

Source of actual value: Wind database.

Table 20. 2017 sample company equity financing rate $y_{4}$.

\begin{tabular}{|c|c|c|c|c|}
\hline \multicolumn{5}{|c|}{$p\left(y_{4}\right)=\frac{\mathrm{e}^{\left(56.708 \times x_{1}+2.73 \times f_{2}+2.045 \times x_{3}-16.775\right)}}{1+\mathrm{e}^{\left(56.708 \times x_{1}+2.73 \times f_{2}+2.045 \times f_{3}-16.775\right)}}$} \\
\hline Company Number & Actual value & Equity financing rate $\mathrm{P}\left(\mathrm{Y}_{4}\right)$ & Predictive value & Consistence \\
\hline 1 & 0 & 0 & 0 & $\sqrt{ }$ \\
\hline 2 & 1 & 1 & 1 & $\sqrt{ }$ \\
\hline 3 & 0 & 1 & 1 & $x$ \\
\hline 4 & 0 & 0 & 0 & $\sqrt{ }$ \\
\hline 5 & 0 & 0 & 0 & $\sqrt{ }$ \\
\hline 6 & 1 & 1 & 0 & $x$ \\
\hline 7 & 0 & 0 & 0 & $\sqrt{ }$ \\
\hline 8 & 1 & 1 & 1 & $\sqrt{ }$ \\
\hline 9 & 0 & 1 & 1 & $x$ \\
\hline 10 & 0 & 0 & 0 & $\sqrt{ }$ \\
\hline 11 & 0 & 0 & 0 & $\sqrt{ }$ \\
\hline 12 & 1 & 1 & 0 & $x$ \\
\hline
\end{tabular}

Source of actual value: Wind database.

reduced the ability to repay debts. Lenders will be wary of lending to shippers, and shippers will also be wary of debt financing under pressure to repay their principal and interest. The selection of the optimal financing method for the enterprise changes with the changes in the internal and external environment. 
Table 21. 2017 Forecasting results of equity financing model.

\begin{tabular}{|c|c|c|c|c|c|}
\hline & \multirow{3}{*}{ Observed } & & \multicolumn{3}{|c|}{ Observed } \\
\hline & & & \multicolumn{2}{|c|}{ Equity financing } & \multirow{2}{*}{ Percentage correction } \\
\hline & & & 0 & 1 & \\
\hline \multirow{4}{*}{ Step 1} & Fouity financino & 0 & 6 & 2 & 75 \\
\hline & Lquity & 1 & 2 & 2 & 50 \\
\hline & Total percentage & & & & 72.7 \\
\hline & \multicolumn{4}{|c|}{ Cutting value .500} & \\
\hline
\end{tabular}

Source: SPSS

These changes are often reflected intuitively in the financial data. Therefore, it is necessary to strengthen the enterprise's financial analysis ability and financial index monitoring.

3) Combining factor analysis and regression analysis methods, four selection models of financing methods are established. Empirical analysis shows that the model has good evaluation efficiency and accuracy. Using established mathematical model, the financial data of shipbuilding enterprise can be input for calculation, then scientific and reasonable financing method selection suggestions are available according to the calculation results.

\subsection{Suggestion}

1) Strengthen financial management capability. Optimal set of financing methods for shipbuilding enterprises is a dynamic process. One of the important indicators during this dynamic change is financial factor, so it is necessary for an enterprise to build a healthy financial control system. In the financial statements, all financial data should be truly reflected, also changes in financial indicators should be timely responded to and the financing methods should be adjusted accordingly. Most importantly, enterprises should manage cash flow carefully, including controlling cost and strengthening management of prepaid/receivable accounts and so on, which requires the cooperation of various departments, not just financial department.

2) Strengthen risk management capability. Shipbuilding is a high-risk industry, which has not only systematic risks such as macro-economic risks, policy-oriented risks and market risks, but also non-systematic risks such as corporate governance risks, financial risks and technical risks. Shipbuilding enterprises should strengthen their awareness of risk management, understand and try different insurance products for shipbuilding enterprises launched by government or financial market, such as export credit insurance and forward foreign exchange settlement business.

3) Grab the policy dividend. Made in China 2025 is China's first action plan to implement the manufacturing power strategy, coupled with huge potential demand brought by the "Belt and Road" strategy, the support for improving China's 
manufacturing competitiveness will gradually increase. Shipbuilding enterprises should seize any opportunity to upgrade themselves, not only exporting a single product, but to export brand-new services.

\subsection{Limitations and Prospects}

Due to the limitations of time and knowledge, there are still many deficiencies in this paper, and some questions need further exploration. The main deficiencies of this paper are as follows:

1) Limitations of factor selection. This paper only considers financial influencing factors when establishing the model. However, factors that influence the selection of financing methods of a company are diverse, including both financial and non-financial factors, such as macroeconomic environment, policy environment, and firm size. It is recommended that subsequent studies can consider both financial and non-financial factors.

2) Financing costs were not taken into account. Financing cost includes fundraising cost and capital cost. In actual operation, financing cost is one of the important considerations for enterprises to choose financing methods. This paper has not considered the impact of financing costs in the construction of selection model. It is suggested that subsequent studies take into account the impact of financing costs.

\section{Conflicts of Interest}

The authors declare no conflicts of interest regarding the publication of this paper.

\section{References}

[1] Guo, X.H. and Qu, L.C. (2008) Analysis of Present Situation of Financing in China's Shipbuilding. Journal of Jiangsu University of Science and Technology (Social Science Edition), 3, 70-74.

[2] Deng, L. (2011) Research on the Current Situation of China's Shipbuilding Financing Channels and International Models. Modern Trade Industry, 1, 144-146.

[3] Shao, R.Q. (2006) International Shipping Ship Investment Decision Methodology. Shanghai Sanlian Bookstore, Shanghai.

[4] Xie, P.P. (2013) Research on Supply Chain Financing of Small and Medium Shipping Enterprises. Logistics Technology, 32, 253-255.

[5] Han, L.X. and Li, T.S. (2010) Research on the Reform Path of Shipbuilding Financing under the Financial Crisis. Financial Problem Research, 2, 53-58.

[6] Zheng, L. (2013) Repayment Responsibility of the Bank under the Advance Payment Repayment Guarantee in the New Shipbuilding Financing. Journal of Dalian Maritime University (Social Science Edition), 6, 60-64.

[7] Wu, X.J. (2013) Innovative Research on Ship Financing in the Construction of Shanghai International Shipping Center. Shanghai Jiaotong University, Shanghai.

[8] Wang, L.X. (2012) Research on Risk Evaluation and Control of Ship Finance Leasing. Chongqing Jiaotong University, Chongqing. 
[9] Ge, A.X. (2012) Research on the Mortgage System of Ships under Construction. Shanghai Jiaotong University, Shanghai.

[10] Nevitt, P.K. and Fabozzi, F. (2000) Equipment Leasing. CFA.

[11] Shen, N.E. and Yeo, A. (2009) Equity Financing within the Shipping and Offshore Marine Industries. Financesia, 7, 16-17.

[12] Albert, S. and Alfred, C. (2011) Financing Shipping Companies and Shipping Operations: A Risk-Management Perspective. Journal of Applied Cooperate Finance, 23, 70-82.

[13] Albertijn, S., Bessler, W. and Drobetz, W. (2011) Financing Shipping Companies and Shipping Operations: A Risk-Management Perspective. Journal of Applied Corporate Finance, 23, 70-82. https://doi.org/10.1111/j.1745-6622.2011.00353.x

[14] Han, T.-C., Chou, C.-C. and Wang, C.-M. (2014) Proceedings of the Institution of Mechanical Engineers, 3, 21-27.

[15] Levy, H. and Sarnat, M. (2013) Leasing. Borrowing and Financial Risk. Financial Management, 8, 47-49.

[16] Monica, B., Mila, G., Lo Andrew, W. and Loriana, P. (2010) Measuring Systemic Risk in the Finance and Insurance Sectors. International Journal of Project Management, 20, 561-567.

[17] Nikolica, D.M. and Jednaka, S. (2011) Project Finance Risk Evaluation of the Electric Power Industry of Serbia. Energy Policy, 39, 168-177.

[18] Gupta, J.P. and Sravat, A.K. (2012) Development and Project Financing of Private Power Projects in Developing Countries: A Case Study of India. International Journal of Project Management, 16, 99-105.

[19] Ebrahimnejad, S., Mousavi, S.M. and Seyrafianpour, H. (2010) Risk Identification and Assessment for Build-Operate-Transfer Projects: A Fuzzy Multi Attribute Decision Making Model. Expert Systems with Applications, 37, 575-586. https://doi.org/10.1016/j.eswa.2009.05.037

[20] Liu, L.J. (2015) The Analysis of Risk Control on Ship Financial Leasing. Dalian Maritime University, Dalian.

[21] Lu, Y.Q. (2011) Risk Assessment of Commercial Banks: A Factor Analysis Based on Annual Reports. Contemporary Finance \& Economics, 6, 55-61.

[22] Zhang, Y.H. (2010) Research on Model to the Listed Company Financing Options. Liaoning University of Engineering and Technology, Fuxin. 